\title{
Identifikasi Pola Pendidikan Karakter Pada Pembelajaran Sejarah Kelas X IPS SMAN 2 Wera
}

\author{
Roni Irawan ${ }^{1}$, Zuriatin $^{2}$ \\ STKIP Taman Siswa Bima \\ roniirawanstkip@gmail.com
}

\begin{abstract}
ABSTRAK
Penelitian ini bertujuan (1) Untuk mengetahui pola pendidikan karakter yang diterapkan pada pembelajaran sejarah di Kelas X IPS SMA Negeri 2 Wera, (2) kendala yang dihadapi oleh guru dan siswa dalam penerapan pola pendidikan karakter pada pembelajaran sejarah di kelas X SMA Negeri 2 Wera. Penelitian ini dilakukan di SMA Negeri 2 Wera menggunakan bentuk penelitian kualitatif deskriptif dengan strategi studi kasus tunggal terpancang. Sumber data terdiri atas informan (guru sejarah dan peserta didik), tempat dan peristiwa (aktivitas belajar sejarah di kelas), dokumen dan arsip. Teknik pengumpulan data menggunakan teknik wawancara mendalam, observasi dan dokumentasi dengan menggunakan teknik purposive sampling. Validitas data menggunakan trianggulasi sumber, trianggulasi data, trianggulasi peneliti dan trianggulasi teori. Analisis data menggunakan analisis interaktif, meliputi reduksi data, penyajian data dan penarikan kesimpulan. Hasil penelitian ini menunjukan bahwa (1) pola pendidikan karakter yang yang diterapkan di SMA Negeri 2 Wera, melalui media-media tertentu yang ditempel didinding sekolah maupun media yang secara langsung. Pola karakter yang ada di sekolah menjadi acuan dalam pelaksanaan pembelajaran sejarah pada siswa kelas X IPS. Pada RPP pembelajaran guru mencantumkan nilai karakter, dan nilai karakter yang dicantumkan akan di evaluasi pada tahap evaluasi pembelajaran. (2) terdapat kendala-kendala yang di hadapai guru maupun siswa dalam penerapan pola pendidikan karakter di kelas X IPS. Kendala-kendala yang menghambat dalam penerapan pola pendidikan karakater yaitu kendala pada waktu, kemampuan siswa dan materi pembelajaran yang pada, serta minimnya media pembelajaran yang dijadikan sebagai contoh dalam menumbungkan karakter siswa.
\end{abstract}

Kata Kunci: Pola, Pendidikan Karakter, Pembelajaran Sejarah

\section{PENDAHULUAN}

Perkembangan Globalisasi dan industri digital akan memberikan ancaman dan tantangan bagi pembentukan karaktek anak bangsa, dimana anak bangsa samakin hari semakin terpengaruh oleh perkembangan globalisasi, perkembangan arus globalisasi ini tentu memberikan ancaman-ancaman yang secara serius terhadap pembentukan karakter anak bangsa yang sesuai dengan landasan kehidupan berbangsa dan bernegara. Dimana nilai-nilai karakter anak bangsa dalam kehidupan sosial budaya disuatu negara dan bangsa sangat penting. Bangsa yang maju adalah bangsa yang memiliki karakter. Dalam membentuk karakter anak bangsa, pendidikan memiliki peren penting dalam membentuk karakter anak bangsa, untuk membentuk karakter yang baik, maka diperluka pola-pola pendidikan untuk memgimplementasi pendidikan karakter.

Pendidikan karakter merupakan salah satu bentuk perwujudan hasil program nasional yang diselenggarakan oleh Kemendiknas para tanggal 14 Januari 2010 tentang "Pendidikan Budaya dan Karakter Bangsa” sebagai gerakan nasional dalam pembentukan karakter bangsa. Gerakan nasional ini didasarkan pada beberapa hal yang menyebabkan tergesernya karakter dan nilai-nilai kearifan lokal bangsa Indonesia yang dimana sikap kebhinekaan dan kegotongroyongan dalam kehidupan masyarakat indonesia sebagai bentuk degradasi moral, ahlak, bergotong royong dan nilai-nilai kearifan lohal bangsa Indonesia. Pada dasarnya pendidikan karakter merupakan usaha ddari pemerintah untuk mewujudkan generasi bangsa yang berkualitas, baik dari segi softskill maupun hardiskillnya. (Yuliana, 2013.1). 
Istilah karakter berasal dari bahasa Yunani charassein dan "kharax" yang maknanya tools for making atau to engrave yang artinya mengukir, kata ini mulai banyak digunakan kembali dalam bahasa Prancis "caracter" pada abad ke 14 dan kemudian masuk dalam bahasa inggris menjadi 'character' sebelum akhirnya menjadi bahasa Indonesia menjadi "karakter" (Alfret Jhon, 2010:VII).

Wacana ini memang sedang hangat dibicarakan pada perkembangan dunia pendidikan di Indonesia, karena ini merupakan terobasan baru dalam perkembangan sejarah pendidikan di Indonesia yang mengusung generasi muda menjadi pribadi yang unggul tidak hanya dalam bidang akademik saja maupun dari segi moral juga yang dianggap perlu diera globalisasi sekarang. Pada penerapan kurikulum 2013 pendidikan karakter di terapkan secara eksplisit melalui KI 1 yang mengandung nilai agama dan KI 2 yang lebih menukik pada nilai sosial sedangkan pada KTSP pendidikan karakter diberikan secara Implisit dalam proses belajar mengajar.

Persoalan budaya dan karakter bangsa kini menjadi sorotan tajam masyarakat. Sorotan itu mengenai berbagai aspek kehidupan, tertuang dalam berbagai tulisan di media cetak, wawancara, dialog, dan gelar wicara di media elektronik. Selain di media massa, para pemuka masyarakat, para ahli, dan para pengamat pendidikan, dan pengamat sosial berbicara mengenai persoalan budaya dan karakter bangsa di berbagai forum seminar, baik pada tingkat lokal, nasional, maupun internasional. Persoalan yang muncul di masyarakat seperti korupsi, kekerasan, kejahatan seksual, perusakan, perkelahian massa, kehidupan ekonomi yang konsumtif, kehidupn politik yang tidak produktif, dan sebagainya menjadi topik pembahasan hangat di media massa, seminar, dan di berbagai kesempatan. Berbagai alternatif penyelesaian diajukan seperti peraturan, undangundang, peningkatan upaya pelaksanaan dan penerapan hukum yang lebih kuat (Kemendiknas, 2010: 1).

Mata pelajaran Sejarah di sekolah, senantiasa memiliki persepsi yang kurang baik. Minat siswa terhadap mata pelajaran sejarah selalu dianggap rendah. Bahkan, Sejarah dianggap sebagai salah satu mata pelajaran yang membosankan dan terkesan tidak menarik dikarenakan pelajaran sejarah dianggap hanya menghafal fakta semata padahal hal ini bertolak belakang dengan tujuan pelajaran sejarah yang banyak mengandung muatan pendidikan karakter. Pembelajaran sejarah bukan sekadar transfer of knowledge tetapi juga transfer of value, bukan sekadar mengajarkan siswa menjadi cerdas, tetapi juga berakhlak mulia. Pembelajaran sejarah, selain bertujuan untuk mengembangkan keilmuan, juga mempunyai fungsi didaktis yang dapat memberikan pelajaran dari pengalaman generasi sebelumnya. Substansi nilai yang diamanatkan pada mata pelajaran sejarah adalah sebagai "Pelajaran yang mengemban misi positif" (Sanusi, 1992: 3).

Alasan perlunya dilakukan identifikasi penerapan pendidikan karakter bangsa yakni keberadaan karakter dalam bangsa merupakan pondasi. Bangsa yang memiliki karakter kuat, mampu menjadikan dirinya sebagai bangsa yang bermartabat dan disegani oleh bangsa-bangsa lain. Oleh karena itu, menjadi bangsa yang berkarakter adalah keinginan kita semua dan selain itu juga didorong oleh kondisi degradasi moral bangsa Indonesia yang pada saat ini tidak terkendali (Kemendiknas, 2010: 1).

Terhadap kondisi tersebut, seharusnya harus mendapat perhatian khusus dari berbagai pihak. Sekolah, sebagai lembaga pendidikan pencetak calon pemimpin bangsa harus ikut bertanggung jawab mengatasi masalah-masalah tersebut. Dari peserta didik inilah, dua puluh lima tahun ke depan mereka yang akan menjadi pemimpin bangsa Indonesia. Oleh karena itu, penanaman Pendidikan Karakter bagi peserta didik di sekolah tidak bisa ditawar lagi.

Sebagai bukti keseriusan pemerintah, Presiden Republik Indonesia, Susilo Bambang Yudhoyono mencanangkan pendidikan karakter pada tanggal 2 Mei 2010 (Jamil: 2012). Dalam impementasinya, pemerintah membuat rencana aksi nasional pendidikan karakter. Dalam rencana tersebut, Kemdiknas membuat 
tigatahapan, yakni tahap I: 2010-2014; Tahap II: 2014-2020; Tahap III: 2020-2025.

Jika dikaji lebih jauh sudah ada sekolah yang sudah menerapkan pola pendidikan karakter dalam pembelajaran sejarah. Terobosan ini diterapkan oleh SMA Negeri 2 Wera. Dengan diterapkannya pola pendidikan karakter di SMA Negeri 2 Wera diharapkan bisa menjadi contoh bagi sekolah-sekolah lain yang belum menerapkan pola pendidikan karakter dalam proses pembelajaran terutama pada mata pelajaran sejarah.

Penelitian ini dilakukan atas dasar dorongan moril sebagai salah satu Dosen Sejarah STKIP Taman Siswa Bima. Hal ini semakin diperkuat dengan wacana pendidikan karakter dalam konteks sekarang sangat relevan untuk mengatasi krisis moral yang sedang banyak terjadi belakangan ini . Diakui atau tidak diakui saat ini terjadi krisis yang nyata dan mengkhawatirkan dalam masyarakat yang melibatkan milik kita yang paling berharga yaitu anak-anak.

Penelitian lainya yang mengkaji lebih mendalam mengenai pendidikan karakter yaitu Budiana (2014) dalam bentuk skripsi berjudul "Pengintegrasian Pendidikan Karakter Dalam Pembelajaran Sejarah Melalui Penerapan Model STAD Sebagai Upaya Pengingkatan Kesadaran Nasionalisme Pada Siswa Kelas XI IPS SMA Negeri 2 Wera". Walaupun telah ada penulisan yang terkait dengan pendidikan karakter namun terdapat persamaan dan perbedaan dengan apa yang penulis kaji pada penelitian ini. Persamaannya terdapat pada kedua peneliti sama-sama meneliti pendidikan karakter dalam proses pembelajaran sejarah.

Peneliti sebelumnya mencoba mengintegrasikan nilai-nilai tersebut pada saat proses pembelajaran sejarah berlangsung, sedangkan perbedaanya terletak pada fokus kajian, peneliti sebelumnya hanya menfokuskan pada pengintegrasian karakter pada pembelajaran sejarah sedangkan penelitian ini menfokuskan pada pola pendidikan karakter pada proses pembelajaran sejarah dengan mengidentifikasi RPP yang dibuat oleh Guru, kemudian proses pelaksanaan pendidikan karakter di kelas pada saat proses belajar mengajar berlangsung, berapa banyak nilai-nilai karakter yang disampaikan oleh guru serta bagaimana respon siswa terhadap pendidikan karakter yang diberikan oleh guru.

Ada 18 nilai -nilai pendidikan karakter yaitu religious, jujur, toleransi, disiplin, kerja keras, kreatif mandiri, demokratis, rasa ingin tahu, semangat kebangsaan , cinta tanah air, menghargai prestasi , bersahabat, cinta damai, gemar membaca, peduli lingkungan ,peduli social dan tanggung jawab. Peneliti memcoba untuk mengali semua nilai-nilai pendidikan karakter bangsa yang diterapkan di SMA Negeri 2 Wera, sehingga nanti muncul suatu kajian yang bisa menjelaskan semua unsur-unsur pendidikan karakter dalam pembelajaran

Adapun beberapa teori yang digunakan dalam penelitian ini untuk memecahkan permasalahan yang dikaji dalam dalam penelitian antara lain: 1) Pengertian/Konsep Pola, (2) Hakekat karakter dan pendidikan karakter, (3) Konsep pembelajaran, (4) pembelajaran Sejarah dan (5) Nilai karakter dalam pembelajaran sejarah

\section{METODE PENELITIAN}

Bentuk penelitian ini kualitatif deskriptif, penelitian yang menyajikan temuan dalam bentuk deskriptif kalimat yang rinci, lengkap dan medalam. Data yang dikumpulkan berupa katakata, kalimat atau gambar yang memiliki arti lebih bermakna dari pada sekedar sajian angkat atau frekuensi (H.B Sutopo, 2006:40). Tujaun dari penelitian ini adalah untuk mengetahui pola pendidikan karakter dalam pembelajaran sejarah di Kelas X IPS SMAN 2 Wera dan kandala-kandala yang di alami oleh guru maupun siswa itu sendiri.

\section{HASIL PENELITIAN}

\section{Pola Pendidikan Karakter di SMA Negeri 2 Wera}

Penelitian ini dilaksanakan di kelas X SMA Negeri 2 Wera pada bulan Agustus sampai Oktober. Berdasarkan hasil observasi, wawancara dan dokumentasi menunjukan bahwa pola pelaksanaan pendidikan karakter di SMA Negeri 2 Wera dilakukan secara menyelur ke semua 
peserta didik di sekolah. pendidikan karakater yang dilakukan secara komprehensif yaitu pendidikan yag dilaksanakan secara menyeluruh di dalam kelas, dalam kegiatan ekstrakurikuler, dalam proses bimbingan dan penyuluhan, dalam upacara bendera dan semua aspek kegiatan di lingkungan sekolah SMA Negeri 2 Wera.

Pendidikan karakter di SMA Negeri 2 Wera dilakukan melalui media-media tertentu dalam proses sosialisasinya di lingkungan sekolah baik pada saat pelaksanaan kegiatan pembelajaran di kelas maupun pada kegiatan ekstrakurikuler. Pelaksanaan pendidikan karakter tidak hanya terbatas pada kegiatan pembelajaran kelas maupun diliingkungan sekolah saja. Pendidikan karakter di sekolah dijadikan sebagai acuan dalam pelaksanaan pendidikan karakter di kelas. sekolah tetap menjadi panyung besar dalam memberikan pembelajaran dan pendidikan yang berkaitan karakter dan sekolah sebagai ujung tombak sebagai ruang pembentukan karakte anak bangsa, selain dari itu sekolah memiliki peran yang sangat vital dalam menanamkan nilai-nilai karakter pada siswa kelas X SMA Negeri 2 Wera. Salah satu media yang ditampilkan dalam menanamkan pendidikan karakter di sekolah yaitu melalui kegiatan ekstrakurikuler yang diprogram oleh sekolah tersebut atara lain kegiatan pramuka sebagai wahana melatih siswa menjadi disiplin, tanggung jawab, kekompokan kelompok, toleransi.

Pola penerapan karakter di tadak saja melalui kegiatan pramuka tetapi banyak kegaiatan yang lain yang akan menjadi wahana dalam pembentukan karakter anak bangsa seperti kegiatan olahraga yang menjadi wahana untuk melatih bakat dalam bidang olahraga. Pola penerapan pendidikan karakter melaui media sekolah membuat mading sebagai wahana melatih siswa yang memiliki kreatifitas pada dunia jurnalistik, melatih siswa dalam rasa ingin tahu, gemar membaca, penduli lingungan dan meningkatkan kesadaran siswa dalam berliterasi.

Sedangkan dalam kelas X IPS guru dalam menerapkan pola pendidikan karakter melalui media pendidikan guru sejarah pada awalnya menyiapkan berbagai perangkat dalam pembelajaran seperti Silabus, RPP, media dan instrumen evaluasi pembelajaran. Berdasarkan hasil observasi, wawancara dan dokumentasi yang di dapat dilapangan peneliti mendapatkan bahwa guru sejarah merumuskan tujuan pembelajaran terlebih dahulu sebelum menetapkan isi dan metode pembelajaran yang dituangkan dalam Silabus dan RPP. Penndidikan karakter menjadi sangat penting bagi anak bangsa, karena bangsa indonesia adalah bangsa yang beragam, lembaga pendidikan sebagai wahana yang memiliki perang yang sangat penting dalam setiap pembelajaran untuk mengimpelementasi pola pendidikan yang berkarakter. Dalam kurikulum 2013, pembelajaran lebih menekankan pada pendidikan karakter seperti membangun kompetensi spritual, intelektual dan kompetensi sosial. Tujuan pembelajaran ini merupakan penjabaran dari Kompetensi yang akan dikuasai oleh setiap peserta didik dan hal ini sudah dirumuskan dalam RPP yang akan diterapkan dalam setiap pembelajaran. metode yang digunakan guru dalam menerapkan pola pendidikan karakter sangat beragam. Dalam materi Tradisi sejarah dalam masyarakat indonesia pada masa pra-aksara dan masa aksara, guru menggunakan motode pembelajaran seperti ceramah dan diskusi, dan model pembelajaran adalah model pembelajaran kooperatif tipe STAD.

Data yang dipaparkan dalam penelitian ini meliputi proses pelaksanaan pendidikan karakter oleh guru dalam proses pembelajaran sejarah untuk memberikan pengalaman belajar kepada siswa, kemudian selain dari itu data yang dihimpun berupa kendala-kendala yang dihadapi oleh guru maupun siswa dalam proses pelaksanaan pendidikan karakter di kelas. oleh karena itu, deskripsi data temuan pada penelitian ini terkait dengan bagaimana cara guru serta respon siswa dalam proses pelaksanaan yang meliputi: a) perencanaan pembelajaran, b) pelaksanaan pembelajaran dan c) evaluasi pembelajaran.

Berdasarkan hasil penelitian di kelas X IPS, guru merancang perangkat pembelajaran sebelum proses pelaksanaan pemeblajaran dilaksanakan atau jauh-jauh hari sebelum kegiatan mengajar berlangsung. Pembuatan 
perangkat pembelajaran yang dilakukan secara bersama-samam kemudian guru melakukan perubahan seperlunya RPP yang telah dibuat sesuai dengan kondisi kelas dan materi ajar yang akan diberikan. Pada setiap RPP yang dibuat oleh guru harus disisipkan unsur-unsur pendidikan karakter di dalamnya.

Pada RPP yang pertama tradisi sejarah dalam masyarakat Indonesia pada Pra-aksara dan masa Aksara guru menyisipkan nilai-nilai karakter didalamnya. Nilai yang disampaikan yaitu dari strategi pembelajaran dan dari materi pelajaran contohnya Dari strategi pembelajaran nilai yang disampaikan yaitu merangsang rasa ingin tahu peserta didik, toleransi, kerja sama, kekompakan dalam kelompok, menghargai pendapat orang lain. Sedangkan dari materi pembelajaran nilai karakter yang dicantumkan yaitu persatuan dan kesatuan, kerja keras, cintah tanah air, bela Negara.

Secara keseluruahan RPP yang pertama sudah tersususn secara sistematis. dalam pembuatan komponen RPP di susun secara sistematis, mulai dari identitas pembelajaran sampai sumber belajar. Sesuai dengan permen diknas nomor 41 tahun 2007 bahwa didalam RPP harus memuat komponen-kom ponen seperti identitas pembelajaran, SK ,KD ,indikator, tujuan pembelajaran, materi ajar, alokasi waktu, metode pembelajaran, kegiatan pembelajaran, evaluasi dan sumber belajar.

Pada tahap pelaksanaan pendidikan karakter di kelas X IPS SMA Negeri 2 Wera peneliti langsung melakukan observasi di kelas X IPS, Peneliti mengobservasi seluruh kegiatan belajar mengajar yang berlangsung dikelas. Berdasarkan hasil temuan peneliti, pelaksanaan pendidikan karakter di kelas X IPS SMA Negeri 2 Wera dilakukan dengan melihat keseluruhan proses pembelajaran berlangsung mulai dari kegiatan pendahuluan, kegiatan inti dan penutup pelajaran serta evaluasi pada pelaksanaan pembelajaran. Pada setiap kegitan pembelajaran guru terlihat menyampaikan nilai-nilai karakter.

Berdasarkan hasil observasi dan wawancara dilapangan, pada proses pelaksanaan pendidikan karakter di SMA Negeri 2 Wera khususnya pada kelas X IPS masih terdapat kendala baik yang dialami oleh guru maupun siswa itu sendiri. Kendala ini akan berpengaruh pada proses penanaman nilai-nilai karakter dalam proses pembelajaran yang mengakibatkan ketidakoptimalan pelaksanaan pendidikan karakter di kelas, namun seperti yang narasumber paparkan bahwa di kelas X IPS pelaksanaan pendidikan karakter sudah berjalan dengan baik.

\section{Kendala-Kendala dalam proses pelaksanaan pola pendidikan karakter}

Kendala-kendala yang dihadapi dalam proses pelaksanaan pola pendidikan karakter di kelas. Salah satu kendala yang paling berpengaruh adalah kendala waktu, hal ini diakui sendiri oleh guru Sejarah di SMA Negeri 2 Wera, pada penerapan kurikulum 2013 waktu pelajaran sejarah yakni 2 jam namun berhubunng SMA Negeri 2 Wera kembali menerapakan KTSP maka jam pelajaran sejarah hanya satu jam saja. Menurut Guru sejarah kendala ini yang menjadi masalah, kalau dikurikulum 2006 (KTSP) pelajaran sejarah mendapat porsi 1 jam pelajaran, pada hari Selasa sam Sejarah Kamis waktu mengajar selama 45 menit masih bisa dipergunakan dengan baik ,sedangkan Senin dan Sabtu waktunya pelajaran terkadang hanya 35-40 menit sehingga waktu tidak dapat dioptimalkan semaksimal mungkin.

Kemudian kendala materi pelajaran yang padat dengan waktu yang terbatas Pada penerapatan KTSP guru sejarah bisa menyampaikan materi dengan tuntas melalui diskusi kelompok. Pada dasarnya yang dilakukan oleh guru sejarah yaitu untuk meningkatkan kemampuan belajar siswa dan mengeksplorasi lebih kemampuan belajar siswa dengan melakukan diskusi kelompok namun hal ini sulit diterapkan di kelas lain namun secara keseluruhan di kelas X IPS kegiatan diskusi berjalan dengan baik seperti yang diakui oleh guru sejarah. Kemudian kendala yang terakhir yaitu dari siswa juga dapat berpengaruh pada optimalnya pelaksanaan proses pembelajaran.

Berdasarkan hasil wawancara membuktikan bahwa kemampuan siswa secara kognitif masih dikatakan kurang. Seperti yang dikatakan oleh narasumber bahwa kemampuan siswa keas X IPS 
beragam ada yang rendah memiliki kemampuan yang sudah bagus. Namun untuk mengatasi masalah tersebut guru memiliki srategi khusus walaupun diakui sendiri oleh guru sejarah sulit diterapakan dengan maksismal, guru sering memberikan persoalan kemudian didiskusikan oleh siswa sehingga metode ini bisa merangsang kemampuan belajar siswa menjadi lebih baik.

\section{KESIMPULAN}

Berdasarkan hasil penelitian dan pembahasan, maka dapat disimpulkan sebagai berikut: 1) Pelaksanaan pendidikan karakter di SMA Negeri 2 Wera dilakukan secara menyeluruh ke semua warga sekolah; 2) Pelaksanaan pendidikan karakter di kelas X IPS secara keseluruhan terencana dengan baik, guru sejarah membuat perencanaan dengan matang dengan menyisipkan nilai-nilai karakter dalam RPP kemudian menerapakannya didalam kelas sehingga penyampain nilai-nilai karakter bisa terlaksana; 3) Dalam pelaksanaan pola pendidikan karakter di kelas X IPS terdapat banyak kendala yang dihadapi baik oleh guru maupun siswa. Kendala ini dapat menghambat dan menimbukan dampak kepada penerapan pola pendidikan karakter dalam proses pembelajaran sejarah berlangsung; 4) Kendala yang dihadapi oleh guru maupun siswa berupa kendala waktu, materi pelajaran yang padat serta kemampuan siswa yang kurang baik menyerap pelajaran yang diberikan oleh guru; 5) Pengembangan nilai-nilai karakter yang diharapkan oleh pihak sekolah dan guru hendaknya tidak hanya dikembangkan dalam kegiatan pembelajaran di kelas dan lingkungan sekolah saja, tetapi juga dilingkungan keluarga dan masyarakat. Hal ini dapat dilakukan melalui komite sekolah dan pertemuan wali murid; 6) Diharapkan kedepanya guru bisa mengatasi dengan baik kendala yang dihadapi oleh guru maupun siswa berupa kendala waktu, materi pelajaran yang padat serta kemampuan siswa yang kurang baik menyerap pelajaran sehingga pelaksanaan pendidikan karakter bisa berjalan dengan maksimal; 7) Guru harus lebih kreatif dan inovatif memadu padankan metode pembelajaran yang sudah ada dan berusaha menciptakan metode-metode baru dalam pembelajaran. Karena pendidikan karakter adalah berpusat kepada kegiatan bukan hanya materi saja.

\section{DAFTAR PUSTAKA}

Aman,2011. Model Evaluasi pembelajaran Sejarah. Yogyakarta: Ombak.

Abd Rahman Hamid, 2014. Pembelajaran Sejarah. Penerbit Ombak.

H. B Sutopo, 2006. Metodelogi Penelitian Kualitatif: Dasar Teori dan Penerapanya dalam penelitian. Surakarta: Universitas Sebelas Maret.

Luk Alfi Hidayah, 2010. Upayah Guru dalam mengatasi Hambatan Pembelajaran Sejarah pda KTSP DI SMP Negeri 39 Semarang. Jurnal Paramita. Volume 20 No.2. Halama 220.

Lexy J. Moloeng, 2002. Metodelogi Penelitian Kualitatif. Bandung: Remaja Rosdakarya.

Made Pidarta, 2009. Landasan Pendidikan. PT. Rineka Cipta.

M. Hosnan, 2014. Pendekatan Saintifik dan Kontekstual dalam pembelajaran abad 21. Penerbit. Ghalia Indonesia.

Oka A Yanti, 1985. Budaya Tradisional Yang Nyaris Punah Bacaan Popular Untuk Perguruan Tinggi. Jakarta. Depertemen pendidikan dan kebudayaan.

Oemar Hamalik, 1986. Media Pendidikan. Bandung: PT. Citra Aditya Bakti

Popha James W, 2008. Transformative Asses Stment USA. Associotion Forr Supervisio and Curiculum Development.

S. K. Kochar, 2008. Teacing of History. Pembelajaran Sejarah. Jakarta: Grasindo.

Suharto, 2009. Museum Kretek Sebagai Media dan Sumber Pembelajaran Sejarah di SMA 1 Gebog Kudus. Tesis. PPs UNS Surakarta.

Tri Widodo, 2011. Memahami Makna Praksis Pelaksanaan Pembelajaran Sejarah Kontroversial. Jurnal Paramita.Volume. 21. No. 2.

Widarto, 2007. Prespektif Global. Salatiga: Widya Sari. 